UDC 330.341.1:634:334.716

(C) 2016

\title{
L. Sleptsova
}

Institute of Horticulture of NAAS

* Scientific adviser - Doctor of Economics O.Yu. Ermakov

\section{TO THE QUESTION OF INNOVATIVE DEVELOPMENT OF GARDENING FACTORIES IN UKRAINE}

The purpose. To study theoretical aspects of development of innovative activity in gardening factories for the solution of existing problems in new measurements of economic space. Methods. Analysis, synthesis, generalization. Results. Some explanations of the concept "innovation" are surveyed. It is studied the following: to what attributes should be categorized innovations and what are their kinds. Theoretical aspects of development of innovative activity are justified and measures for rising its efficiency in gardening factories are offered. The gear of implementation of innovative-intensive technologies of production of fruits and berries is specified. Conclusions. Innovative processes play an important role in economic development of gardening factories and make it possible to create competitive subjects of market managing.

Key words: innovation, innovative activity, economic efficiency, gardening factories, intensification, innovations, stocks, scientific and technical advance.

$21^{\circ}$ centuries you know as a century of innovations. According to it in our country is actual the conversion to the all sectors of the national economics on the innovation's model of economics development for more effective working. According to the Ukraine's law "About innovations activity" are law economic and organizes forms their stimulations process so it straight on economics development for the innovation's way. Scientific and technical advance was and now base of the intensifications of the agriculture and horticulture as one of the most intensification their sectors. Scaling using of the innovations may be increasing of the plantation's harvesting and their economical efficiency.

Analyses of the new scientific works. The problems of economics innovation's development was devoted many scientific works of the national and foreign politic scientists-economics: Dacia O., Volkova O., Besheleva S., Gurvicha F., Vinichenka I., Filipsa Edmunda, Dubansa Davida, and Ermacova O., Shestopalia O., Y. Yurchishina Rulieva V. - in horticulture etc. But some questions in horticulture are needed to improving and additional of the economical organization mechanism to the activization of innovations activity. Its important: the 
modern state its regulations doesn't"t answer modern needs yet so as necessary complex methodological gist. Article"s objective - investigations of the theoretical aspects of the development of the innovations activity on the horticultures organizations for deciding of the problems on new dimensions economical areas.

Due to development of the public farm the gist of termin "innovation" is broaden. Now some aspects. Some of scientists economists take their as a practice using of new products that common in systems or are formed such systems of production activity that wasn"t using in practical production [3].

Innovation advances not only as a result of scientific technical activity or activity in common but as a result that was application in public production. Shestopal O. states this termin as a new product in produce of new technologies and types of productions, high organizing structures of produces and working [9 p.108].

Beshelev S. and Gurvich F. Distinguish such types of new products [2, p.4950,145-148]:

- productiveness, directing to the productive process and using of new products - things of the producing and things of the consumptions;

- technological that directing to the forming and using the new technologies;

- social - directing to the building and functional new economic organizes and another structures and economical mechanized;

- Complex that common such types.

Dependent to the innovation potentialit Daciy O. singles out such types of innovations [3]:

- Radicals or bases (principle new technologies, directions methods, types of production);

- Combinatorics (using different links of the constructive element's joining);

- Modified (improving and additional construction"s emerging principles, forms). Moreover to the subjects contents innovatios may be divided on:

- bases, that provide radical reforms in certain sphere (forming new generations and tendencies of technique, technological varieties and methods, new economical and social political public, revolution in science, culture, education etc.);

- improving, directing on differentiation and broading of the bases innovations 
with more taking into account specific demands of the different spheres applications and groups of consumers;

- micro innovations, that bring part improving in using products, technologies, methods of the organizathions that based of the technical improving rationalized proposals; pseudo innovations, that pointed of the innovation"s activity and plays negative roles.

Some another approaching to this questions in anouters authers. For example Volkov O.

Classified the new products for such capacities [11]:

- degree of radicalisms (mew's degree, innovationless, potentials, originalities of the technical decides etc.) - radicals (pioneers, bases, scientific etc.), ordinary (discoveries, new technical deciding);

- character of using (products, technological, socials complex, marketing) directing on produce and using to the new products, building and functioning of the new structures, aimed on formed and using to the new technologies;

- stimulus of appearance (sources) - novelties, caused by the development of science and technics, by the requirements of production and market;

- role in the reproduction process - consumer and investment;

- scale (complexity) - complicated (synthetic) and simple;

- for whom are they novelties ? - for producer ? consumer ? the entire society ? for the market?

Thus one may state that innovation is introduction of novelties that provide increase of manufacturing products which are in demand at the market.

The market of the innovative horticultural production has its specific economic mechanism directed to the ensuring of the mutual interests of the branch scientific institutions which are developers of the production and manufacturers that are its consumers (agricultural and private enterprises, farmsteads). This is totality of economic organizational financial relations and those governed by law that appear between scientific establishments (institutes, research stations) of horticulture of NAAS of Ukraine, meditative organizations on the innovative production market (innovative stock exchange, leasing companies, patent standardization and certification organizations), on the one hand, and its immediate consumers (agricultural enterprises, farmsteads and personal peasant farms), on the other 
hand, in the process of the exchange of the innovation activity results. The innovation market includes not only innovative production but also organizations, collectives, individual experts that are potentially capable of carrying out innovation activity which is a purposeful direction of a concrete horticultural enterprise as concerns the determination of the priority manufacturing of certain kinds of fruits and small fruits by means of introducing advanced technologies, new cultivars and novelty technological achievements, improving the organization of production and salaries and wages for the purpose of increasing the fruits and small fruits products and achieving maximum profit.

In Ukraine horticultural enterprises have the following scheme of the innovation provision (fig.1).

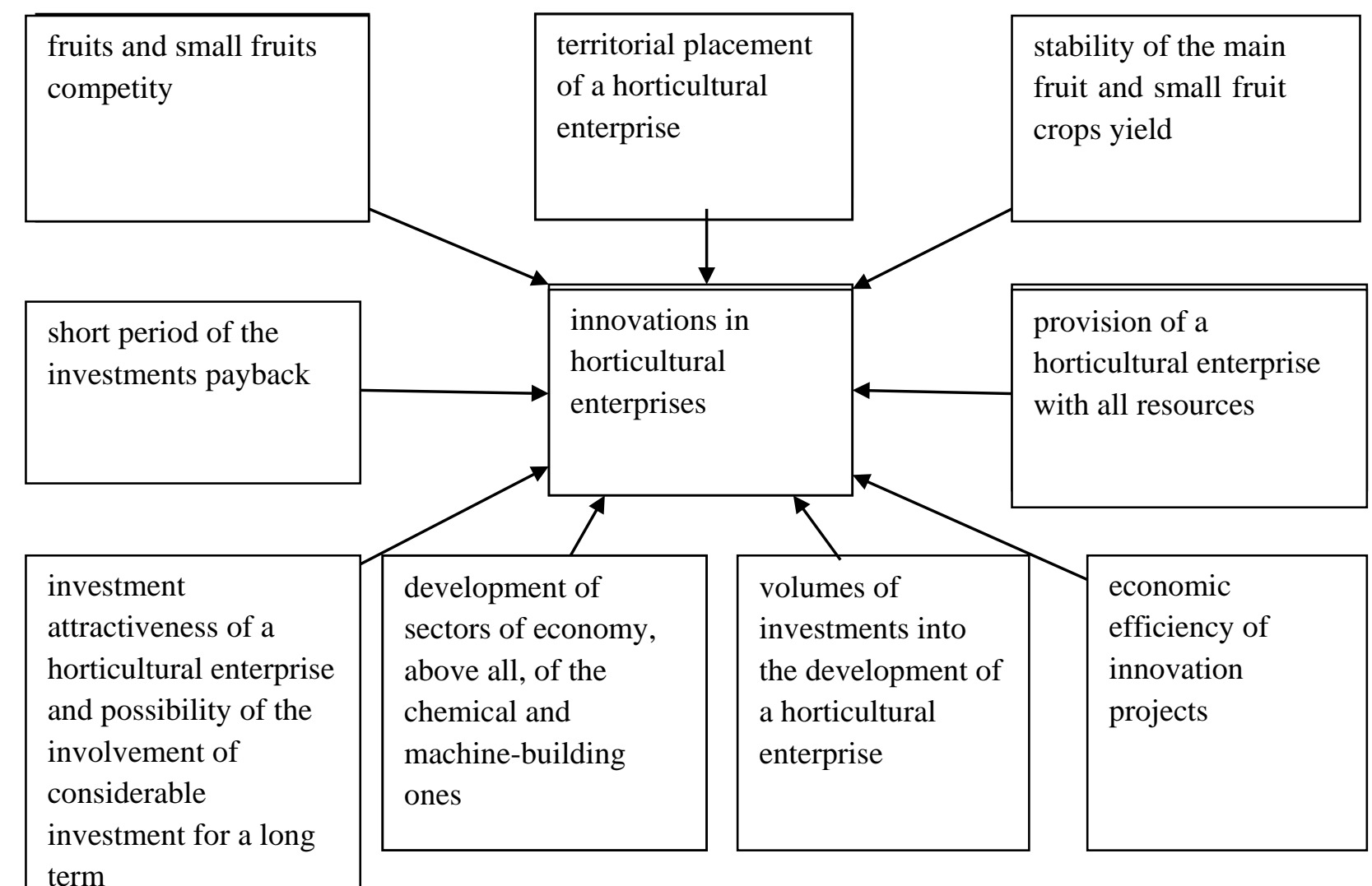

Figure1. Main factors that influence the innovations formation in horticultural enterprises Adapted by the author source [7]

The process of the formation of the innovation production market in the industrial horticulture depends considerably on the period of creating new fruit crops cultivars and elaborating technologies of fruits and small fruits growing. In this connection T.Y. Kondratenko notes that in the latest 50 years apple orchards are grown under the intensive and integrated technologies involving for their establishment cultivars with other biological and business characteristics. A consumer has changed requirements to fruit products too. That's why necessity 
has appeared to accelerate considerably breeding, testing and propagation of the best cultivars. 50 years ago it took 47-50 years to create new fruit crops. Today when the breeding process is intensified this period can be reduced to $10-15$ years [6].

It is known that the main means of production in horticulture are fruit and small fruit orchards which function on one place for many years. There fore it is necessary to create them on the basis of the newest achievements of the scientific and technical progress, that is on the innovation ground. The innovation process in a horticultural enterprise is to be accomplished constantly, that is caused by the fact that:

1) introduction of innovations (intensity of technologies, cultivars, machines and so on) is brought about by the competition of fruits and small fruits producers that results in the provision of the products competity;

2) the horticultural farms which constantly introduce, innovations gain stable supplementary profits owing to the temporary monopoly at the fruit and small fruit products;

3) the innovation development of even not large horticultural enterprise contributes to its transformation to a powerful producer of competitive fruit and small fruit products.

V.A.Rulyev looked upon the innovation process in horticulture as the totality of labour operations on the produce, spread and use of fruit and small fruit products and application of technologies for their production that would possess scientific and technical novelty and meet the market requirements [7, c.259]. The innovation process efficiency is determinet after the introduction of the novelty into production and achievement of profit and the process itself consists of the following structural stages: researches $\rightarrow$ scientific elaborations $\rightarrow$ experimental production (experiment, research trial) $\rightarrow$ production $\rightarrow$ sale (consumption).

It is important to note the distinctive characteristics of the horticulture intensification which lies in the fact that the introduction of progressive technology elements in a concrete farm is not always connected with additional expenditures. The example is the substitution of fruit and small fruit crops cultivars of little value for more productive ones, timely and high quality conduct of operations on the care of orchards etc. Carrying out a number of agrotechnical measurements, increase of the mechanization level in the branch ensures the economy of total expenditures. 
That's why the intensification process in horticulture, like in other agricultural sectors, may not be characterized one-sided. It should be estimated as a complex taking into consideration both the level of the expenditures material means of labour, volumes of the applied main production means and the efficiency of the land usage (multi-year orchards) and all the other elements of production.

The mechanism of introducing innovative and intensive technologies for producing fruits and small fruits lies in the payback of the following activity forms and management methods [7, c.260]:

- reveal of propositions at the sector innovations market; elaboration and patent of the innovative and intensive technology by a branch scientific institution;

- transfer of the innovations (intensive technology, new cultivar and so on) to a horticultural enterprise according to a license agreement ;

- introduction of the technologies, new cultivar under the supervision of

- the innovations elaborator and determination of their economic efficiency.

The most important innovations direction in the industrial horticulture is development, production test and spread to farms of new high intensive technologies for growing fruits and small fruits. Doubtless, it is connected with the necessity of taking into consideration in full biological peculiarities of cultivars and rootstocks which are the whole element of the main means of production. At the same time the present-day intense orchards under their construction must be absolutely adapted to the environment conditions, suitable for the soil management and care of the trees and thanks to this provide high labour productivity and yield of pome crops within 40-45t/ha, stone fruit ones - 10-12 t/ha.

Multi-year researches of the scientists of the institute of Horticulture of NAAS of Ukraine have shown that the yield of a number of apple cultivars depends directly on the type of rootstocks. In the orchards on the clonal rootstocks under densed planting plans and yield increase the demand of fertilizers rises which is met both through their use and due to reserves of nutritive elements in soil. The influence of the latter factor increases because of the rise of the fertilizers price.

At present the problem of the establishment of high-productive orchards on seed rootstocks without exhaustion of the ecological resources is the most complicated one in the agricultural production. It was caused by the long-term orchard agrosystems rotation brought about by the cultivars and rootstocks biological peculiarities and by the modern technologies. All the monoculture 
drawbacks are character istic of such orchards that cause the soil exhaustion, accumulation of toxic substances in it, negative allelopathic influence. There fore it is necessary to change technological approaches to using orchard ecosystems so that those systems be based on the principles of decreasing technogenic loads on cultivars.

In the present-day commercial fruit growing it is of great importance to establish new orchards on clonal rootstocks with the formation of such crowns which would support the generative function and restrain the vegetative one [10, c.133-143].

\section{Conclusions}

The innovation processes play an important role in the economic development of horticultural enterprises and make it possible to create competitive market participants. For the high efficient innovation activity it is necessary to create optimum conditions at such enterprises, namely: introduction of novel technological achievements, improvement of the organization of production and of wages and salaries, substitution of cultivars of fruit and small fruit crops which are of small value for more productive ones, timely and high quality conduct of operations on taking care of orchards, increase of the mechanization level in the sector, reveal propositions at the branch innovation market, elaborate and patenting of innovative and intensive technologies by a branch scientific institution, transfer of innovations to a horticultural enterprise under the license agreement. All these measures are to be carried out under the scientific supervision of the innovations elaborator with calculating their economic and conducting the production revision of new high intensive technologies for growing fruits and small fruits in order to introduce them in farms.

\section{Bibliography}

1. Zakon Ukrainy "Pro innovaciinu dial'nist"//Vidomosti Verchovnoi Rady Ukrainy. - 2002. - №36. S.266

2. Bieshieliev S.D., Gurvicz F.G. Novovviedienie i my. - M.: Nauka, 1990. - 250 s.

3. Dacii O.I. Innovacii ta innovacciina dial'nist: sutnist' i sunkcii v agropromyslovomu vyrobnyctvi//Visnyk sums 'kogo nacional’nogo agrarnogo universytetu/ Seriia “Finansy I kredyt”. -2003. - №2. - C.123-128. 
4. Dacii O.I. Metodyczni osnovy doslidzhennia innovaciinogo rozvytku galuzei sils`kogo gospodarstva //Agrosvit. - 2008. - №14. - S.15-18.

5. Dacii O.I. Rozvytok innovaciinoi diial’nosti v agropromyslovomu vyrobnyctvi Ukrainy.- - K.:NNC, IAE, 2004. - 428 c.

6. Kondratenko T.le. Sort iabloni. Dolgaia doroga v sad//Ovoshczi i frukty. 2014. - Diekabr'. - S.68-73.

7. Ruliev V.A. Konkurentospromozhnist plodiv i iadid. Melinopol`. TOV "Vydavnyczyi budynok MMD", 2007. - 315 s.

8. Shestjpal`A.N. Vosproizvodstvo i effiektivnost` produktivnogo ispol’zovaniia plodovych i iagodnych nasazhdienii. - K.: Sil'gospjsvita, 1994. - $256 \mathrm{~s}$.

9. Shestjpal O.M. Metodyka ekonomicznoi ta energetycznoi ocinky typiv nasadzhen`, sortiv, investycii $v$ osnovnyi kapital, innovacii ta rezul'tativ technologicznych doslidzhen u sadivnyctvi. - K., 2006. - $140 \mathrm{~s}$.

10. Ekonomika ta organizaciia promyslovogo sadivnuctva Ukrainy/ Sestopal O.M., Vuliev` V.A., Kondratenko P.V. ta in. - K.:NNC «Instytut agrarnoi ekonomiky», 2010. - $334 \mathrm{~s}$.

11. 11. Herbel. D. Good Practices in Building Innovative Rural Institutions to Increase Food Security/D. Herbel, E. Crowley, N. Ourabah Haddad. - Rome: IFAD - FAO, 2012. - 120p. 